\title{
Multiple Biological Actions of Curcumin in the Management of Diabetic Foot Ulcer Complications: A Systematic Review
}

Kuppusamy Gowthamarajan ${ }^{*}$, Veera Venkata Satyanarayana Reddy Karri, Satish Kumar MN and Rajkumar Malayandi

${ }^{1}$ Department of Pharmaceutics, JSS College of Pharmacy, Ootacamund, JSS University, Mysore, India

${ }^{2}$ Department of Pharmacology, JSS College of Pharmacy, Ootacamund, JSS University, Mysore, India

${ }^{3}$ Pharmacokinetic Research and Development, Sun Pharmaceutical Industries Ltd, Part Survey No. 27 C.S No.1050, Village Tandalja, Baroda, India

*Corresponding author: Kuppusamy Gowthamarajan, Department of Pharmaceutics, JSS College of Pharmacy, Rocklands, Udhagamandalam, Tamil Nadu, India 643001, Phone: +91 423 2443393. Ext.216; E-mail: gowthamsang@gmail.com

Received date: January 19, 2015, Accepted date: February 11, 2015, Published date: February 15, 2015

Copyright: (c) 2015 Kuppusamy Gowthamarajan et al. This is an open-access article distributed under the terms of the Creative Commons Attribution License, which permits unrestricted use, distribution, and reproduction in any medium, provided the original author and source are credited.

\begin{abstract}
Diabetic foot ulcers (DFUs) or diabetic wounds are the major causes of death in patients with diabetes. Curcumin is the principal curcuminoid of turmeric (a member of ginger family), widely used as a dietary spice and coloring agent. Curcumin possesses potent anti-inflammatory, anti-oxidant and anti-infective properties which makes this molecule a worthy candidate for wound healing and other inflammatory diseases. Curcumin has garnered greater attention in the past few decades in treating diabetes and its complications. However, very few studies are available in relation to curcumin as a diabetic wound healing agent with the underlying mechanisms still in the dark. Hence, this paper discusses the possible uses of curcumin in treating DFUs with the corresponding mechanisms at different junctures of diabetic wound healing. This review also summarizes the various in vitro and in vivo studies established/ reported on curcumin in treating DFUs.
\end{abstract}

Keywords: Curcumin; Diabetes; Diabetic foot ulcer; Diabetic wound; Chronic wound

\section{Introduction}

The World Health Organization (WHO) has published findings suggesting the total number of people suffering with diabetes mellitus (DM) to have crossed 347 million. In 2012 alone, the management of diabetes in the USA raked up a bill of $\$ 245$ billion [1]. People suffering from diabetes have a $25 \%$ risk of developing a foot ulcer during their lifetime, half of which get infected, if untreated, results in amputation. Every year, almost 83,000 lower limb amputations are performed due to DFUs, also associated with mortality in some cases [2]. As the number of diabetics increase each year, the burden of treating DFUs also rises in tandem. The average cost for treating infected DFUs is USD 17,000, while a major amputation costs USD 45,000 . DFUs are the major cause of deaths in people with DM [3]. DFUs occur as a consequence of multiple pathologies (neuropathy and angiopathy or ischemia) which lead to infections. Current treatment focuses on patient education, early diagnosis and prevention. The current disparity in the health care system is such that noninvasive therapies are less effective and invasive therapies are expensive [4]. None of the existing treatments can fulfill the overall pathological requirements of DFUs and in addition, no single combinational therapy has been approved in treating DFUs till date [5]. Curcumin is obtained from the ginger herb (Zingiber officinale), widely used as a dietary spice and coloring agent. The rhizome is the most commonly used part of the plant in treating many diseases. Of the three curcuminoids present, curcumin (77\%) is most prominent $(17 \%$ demethoxycurcumin and 3\% bisdemethoxycurcumin) [6]. Curcumin has been known to possess anti-inflammatory, anti-oxidant, antiinfective, angiogenic and nerve healing properties [7]. Hence, curcumin application in the treatment of DFUs may not only heal the wound, but also synergize the overall wound healing effect through various mechanisms. This paper discusses the possible uses of curcumin in treating DFUs with each of its corresponding mechanisms at different phases of diabetic wound healing. Also, a summary of the preclinical studies performed with curcumin in treating DFUs is included.

\section{Pathophysiology}

The etiopathogenesis of DFUs is complex and multifactorial (Figure $1)$.

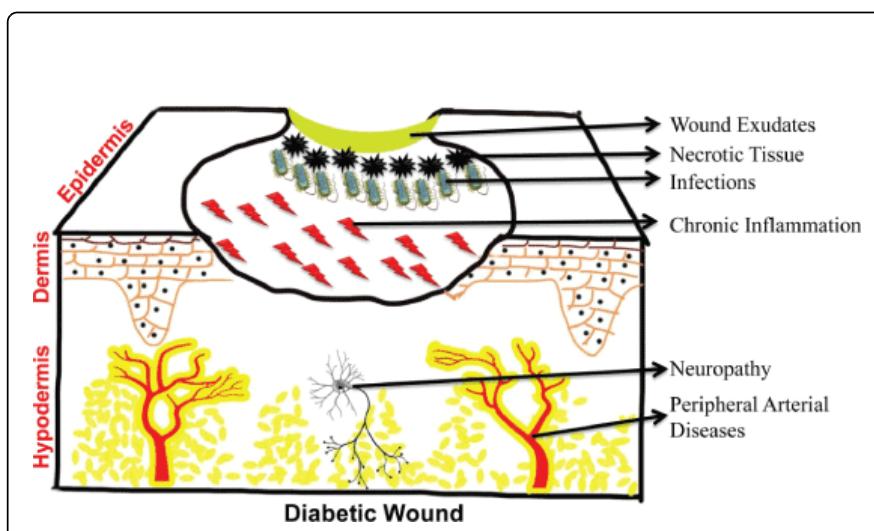

Figure 1: Pathophysiological complications in treating DFUs

Diabetic wounds differ from normal, acute wounds in various aspects. DFUs remain static at the chronic inflammation state, when compared to acute wounds. The detailed difference between diabetic and acute wounds is described in Table 1. 


\begin{tabular}{|c|c|}
\hline Diabetic Wound & Acute wound \\
\hline $\begin{array}{l}\text { Diabetic wounds are caused by both internal etiology and external injury and refuse to } \\
\text { heal if unaided. }\end{array}$ & $\begin{array}{l}\text { Acute wounds are caused by a recent injury and usually healed with no } \\
\text { treatment. }\end{array}$ \\
\hline They can be triggered by injury, but prolonged by other underlying medical conditions. & This will speed up the healing process and reduce scarring. \\
\hline $\begin{array}{l}\text { Diabetic wounds become 'stuck' in the inflammatory and proliferative stages of healing } \\
\text { which delays closure. }\end{array}$ & $\begin{array}{l}\text { There is rapid progression of acute wounds with the activation of the clotting } \\
\text { factors immediate to wound occurrence }\end{array}$ \\
\hline $\begin{array}{l}\text { The epidermis fails to migrate at the wound margins, which interferes with normal } \\
\text { cellular migration over the wound bed. }\end{array}$ & $\begin{array}{l}\text { In general situations, the epidermis migrates to the wound margin upon drying } \\
\text { of the fibrin clot }\end{array}$ \\
\hline Presence of neuropathy and peripheral arterial diseases. & Absence of neuropathy and peripheral arterial diseases. \\
\hline $\begin{array}{l}\text { In Diabetic wounds there appears to be an over production of matrix molecules } \\
\text { resulting from underlying cellular dysfunction and disregulation (Debridement) }\end{array}$ & May not be present and depends on extent of injury \\
\hline $\begin{array}{l}\text { Debridement is often required more than once as the healing process can stop or slow } \\
\text { down allowing further devitalized tissue to develop. }\end{array}$ & $\begin{array}{l}\text { In acute wound, debridement is usually not required as the dried wound } \\
\text { generally breaks down upon new tissue formation underneath }\end{array}$ \\
\hline $\begin{array}{l}\text { The signs of diabetic wound are delayed healing, increased exudates, bright red } \\
\text { discoloration of granulation tissue, friable and exuberant tissue, new areas of slough, } \\
\text { undermining, pain, malodor and wound breakdown }\end{array}$ & Most of these signs are absent in acute wound. \\
\hline $\begin{array}{l}\text { Diabetic wound fluid has been found to contain high levels of proteases which have an } \\
\text { adverse effect on wound healing by slowing down or blocking cell proliferation in } \\
\text { particular keratinocytes, fibroblasts and endothelial cells. }\end{array}$ & $\begin{array}{l}\text { Acute wound fluid supports the stimulation of fibroblasts and the production of } \\
\text { endothelial cells as it is rich in leukocytes and essential nutrients. }\end{array}$ \\
\hline
\end{tabular}

Table 1: Comparison of diabetic and acute wound

Unlike most diseases and disorders, DFUs will not arise as a result of a single pathological consequence. Among the various factors, neuropathy and peripheral vascular diseases (PVD) are the most common causes of DFUs. Prolonged/excessive glucose deposition in blood leads to the damage of peripheral nerves (peripheral neuropathy). Depending on the type of damaged nerve, neuropathy may be sensory, motor or autonomic. Sensory neuropathy leads to loss of sensation on the surface of the foot [8]. In case of painful sensory neuropathy, drugs like serotonin-norepinephrine reuptake inhibitors, anticonvulsants, tricyclic and tetracyclic anti-depressants are prescribed for the symptomatic relief of pain. In motor neuropathy, imbalance between extensor and flexor muscles leads to the development of abnormal pressure, resulting in callus formation [9]. Autonomic neuropathy contributes to reduced blood supply to the feet ensuing in decreased moisture content, causing the feet to be vulnerable to cracks [10]. Finally, the formed callus (in motor neuropathy) accompanied with sensory loss (in sensory neuropathy) and reduced moisture (in autonomic neuropathy) ruptures and effects the formation of a DFU. Unlike acute wounds (maintained at hemostasis), if DFUs are untreated in the early stages, amputation is the most eventual outcome. The decreased blood supply in PVD further worsens the condition of DFUs.

\section{Physical and Molecular Properties of Curcumin}

Curcumin is a bright yellow powder which provides yellow pigmentation to turmeric and generally used as a dye (E100) in the food industry. The powder extract constitutes $75 \%$ curcumin, $16 \%$ demethoxycurcumin and $8 \%$ bisdemethoxycurcumin with a small amount of cyclocurcumin [11]. Chemically, curcumin (Figure 2) is a bis-R-unsaturated-diketone (commonly called diferuloylmethane). It is a poly-phenolic molecule existing in two forms (keto and enol) of which the enol form is more stable in both solution and solid states. This lipophilic molecule has two aromatic rings connected by two unsaturated carbonyl groups and therefore has poor water solubility [12]. The hydrogen bond-stabilized-central hydroxyl group is an important functional site responsible for an array of molecular biological activities. The photosensitive nature of curcumin and poor solubility hinders its therapeutic application [13]. The influence of curcumin in chronic wound healing is attributed to its biochemical effects such as its antioxidant [14,15], anti-inflammatory and antiinfective activities [16,17].<smiles>COc1cc(/C=C/C(=O)CC(=O)/C=C/c2ccc(O)c(OC)c2)ccc1O</smiles>

Figure 2: Curcumin structure

\section{Multiple Biological Activities of Curcumin in Various Aspects of Diabetic Wound Healing}

Curcumin exhibits multiple biological activities in treating various aspects of DFU complications (Figure 3). The each biological activity with its corresponding mechanism is discussed in this section (Table 2). 
Citation: Karri VVSR, Gowthamarajan K, Satish Kumar MN, Rajkumar M (2015) Multiple Biological Actions of Curcumin in the Management of Diabetic Foot Ulcer Complications: A Systematic Review. Trop Med Surg 3: 179. doi:10.4172/2329-9088.1000179

Page 3 of 6

\begin{tabular}{|c|c|c|c|c|}
\hline Trial/Study & Animal Model & Curcumin Regimen & Effect observed & Reference \\
\hline $\begin{array}{l}\text { Effect of Curcumin on the Advanced } \\
\text { Glycation and Cross-linking of Collagen in } \\
d \text { Cross-linking of Collagen in Diabetic } \\
\text { Rats }\end{array}$ & $\begin{array}{l}\text { STZ induced } \\
\text { diabetic rats }\end{array}$ & $\begin{array}{l}200 \mathrm{mg} / \mathrm{kg} \text { once daily } \\
\text { orally for } 8 \text { weeks }\end{array}$ & $\begin{array}{l}\text { Reduction in oxidative stress and lipid peroxidation } \\
\text { products was observed. Prevented accumulation of } \\
\text { advanced glycation end products (AGEs). }\end{array}$ & $\begin{array}{l}\text { Sajithlal et al. } \\
(1998) \\
{[56]}\end{array}$ \\
\hline $\begin{array}{l}\text { Curcumin enhances wound healing in } \\
\text { streptozotocin induced diabetic rats and } \\
\text { genetically diabetic mice }\end{array}$ & $\begin{array}{l}\mathrm{STZ} \text { induced } \\
\text { diabetic rats } \\
\text { and } \mathrm{db} / \mathrm{db} \text { mice }\end{array}$ & $\begin{array}{l}40 \mathrm{mg} / \mathrm{kg} \\
\text { orally and } 0.1 \% \\
\text { topically }\end{array}$ & $\begin{array}{l}\text { Increase in TGF-b1. Enhanced re-epithelialization, } \\
\text { neovascularization, improved migration of dermal } \\
\text { myofibroblasts, fibroblasts and macrophages into the } \\
\text { wound bed along with higher collagen content }\end{array}$ & $\begin{array}{l}\text { Sidhu et al. (1999) } \\
\text { [53] }\end{array}$ \\
\hline $\begin{array}{l}\text { Curcumin Loaded Poly }(\varepsilon-\text {-Caprolactone) } \\
\text { Nanofibers: Diabetic Wound Dressing with } \\
\text { Antioxidant and Anti-inflammatory } \\
\text { Properties }\end{array}$ & $\begin{array}{l}\text { STZ induced } \\
\text { diabetic rats }\end{array}$ & $\begin{array}{l}17 \% \quad \text { curcumin } \\
\text { topically for } 10 \text { days }\end{array}$ & $\begin{array}{l}\text { Reduced oxidative stress and inflammation (low levels } \\
\text { of IL-6 release). }\end{array}$ & $\begin{array}{l}\text { Merrell et al. (2009) } \\
{[54]}\end{array}$ \\
\hline $\begin{array}{l}\text { Antioxidant and anti inflammatory } \\
\text { potential of curcumin accelerated the } \\
\text { cutaneous wound healing in } \\
\text { streptozotocin-induced diabetic rats }\end{array}$ & $\begin{array}{l}\text { STZ induced } \\
\text { diabetic rats }\end{array}$ & $\begin{array}{l}0.3 \% \text { per day } \\
\text { topically for } 19 \text { days }\end{array}$ & $\begin{array}{l}\text { Decreased the expressions of inflammatory cytokines } \\
\text { (TNF- } \alpha, \text { IL-1 } 1 \beta \text { and matrix metalloproteinase-9). Increased } \\
\text { the levels of anti-inflammatory cytokine (IL-10) and } \\
\text { antioxidant enzymes (superoxide dismutase, catalase and } \\
\text { glutathione peroxidase). }\end{array}$ & $\begin{array}{l}\text { Kant et al. (2014) } \\
{[51]}\end{array}$ \\
\hline $\begin{array}{l}\text { Curcumin-induced angiogenesis hastens } \\
\text { wound healing in diabetic rats }\end{array}$ & $\begin{array}{l}\text { STZ induced } \\
\text { diabetic rats }\end{array}$ & $\begin{array}{l}0.3 \% \text { per day } \\
\text { topically for } 19 \text { days }\end{array}$ & 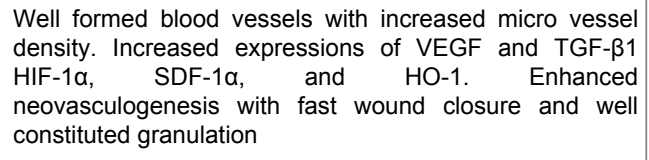 & $\begin{array}{l}\text { Kant et al. (2015) } \\
\text { [55] }\end{array}$ \\
\hline $\begin{array}{l}\text { Curcumin Could Prevent the Development } \\
\text { of Chronic Neuropathic Pain in Rats with } \\
\text { Peripheral Nerve Injury }\end{array}$ & $\begin{array}{l}\text { STZ induced } \\
\text { diabetic rats }\end{array}$ & $\begin{array}{l}50 \mathrm{mg} / \mathrm{kg} \text { once daily } \\
\text { orally for } 7 \text { days }\end{array}$ & $\begin{array}{l}\text { Reduced expression of } \mathrm{p}-\mathrm{ERK}, \mathrm{p}-\mathrm{JNK} \text { and } \mathrm{p}-\mathrm{NR} 1 . \\
\text { Reversed mechanical allodynia and spontaneous nerve } \\
\text { pain. }\end{array}$ & $\begin{array}{l}\text { Jeon et al. (2013) } \\
{[57]}\end{array}$ \\
\hline $\begin{array}{l}\text { Effect of curcumin on diabetic peripheral } \\
\text { neuropathic pain: } \\
\text { Possible involvement of ossible } \\
\text { involvement of ipheral Opioid system }\end{array}$ & $\begin{array}{l}\mathrm{STZ} \text { induced } \\
\text { diabetic rats }\end{array}$ & $\begin{array}{l}50 \mathrm{mg} / \mathrm{kg} \text { once daily } \\
\text { intra peritoneal for } 14 \\
\text { days }\end{array}$ & $\begin{array}{l}\text { Prevented the weight loss and attenuates mechanical } \\
\text { allodynia. }\end{array}$ & $\begin{array}{l}\text { Banafshe et al. } \\
(2014) \\
{[58]}\end{array}$ \\
\hline
\end{tabular}

Table 2: Preclinical trials on curcumin in treating DFUs

\section{Curcumin in diabetic neuropathy (DN)}

About $50 \%$ patients with diabetes in their lifetime will develop neuropathy. This results due to nerve damage by high blood glucose levels.

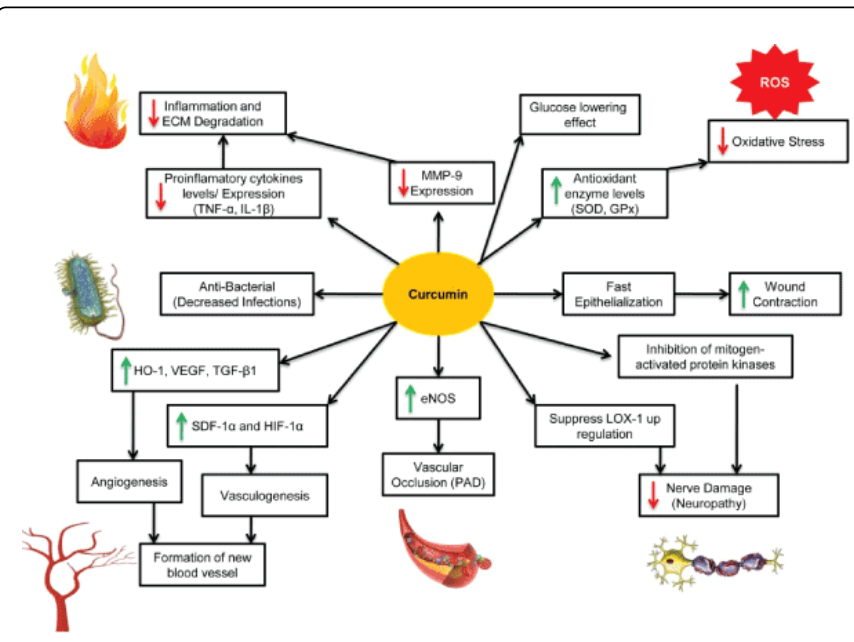

Figure 3: Curcumin mechanism of actions in treating DFUs
Curcumin has been reported to exhibit neuro-protective activity in tardive dyskinesia, Alzheimer's disease, epilepsy, major depression and other related neurodegenerative and neuropsychiatric disorders [18].

The neuroprotective mechanism of curcumin is not clear; however, it has been hypothesized for its anti-inflammatory and antioxidant properties.

The oxidative stress induced by hyperglycemia in peripheral nerves causes activation of the nuclear factor kappa-light-chain-enhancer of activated $\mathrm{B}$ cells $(\mathrm{NF \kappa B})$ transcription factor. The generation of NFkB mediated proinflammatory cytokines, including tumor necrosis factor (TNF- $\alpha$ ), interleukin (IL)-6, inducible nitric oxide synthase (iNOS) and cyclooxygenase (COX)-2 leads to neuroinflammation-mediated nerve damage. Generation of reactive oxygen species causes the degradation of endogenous antioxidant defenses such as glutathione, uric acid and bilirubin [19]. Osawa and Kato [20] have observed that curcumin inhibits the development of streptozotocin (STZ) - induced DN by antioxidant defenses. Sharma et al. [21] have observed that the combination of resveratrol with curcumin has high efficacy in preventing STZ induced alterations in sensory and motor functions when compared to resveratrol alone. Similar findings were also observed by Attia et al. [22] when they used the combination of gliclazide and curcumin. Zhao et al. [23] have demonstrated the anti TNF- $\alpha$ activity and nicotinamide adenine dinucleotide phosphate (NADP)-oxidase inhibitory effect of curcumin by which it improves the sensory-motor disturbances of diabetic neuropathy. Joshi et al. 
[24] have reported that curcumin reduced the expression of proinflammatory mediators such as TNF- $\alpha$, IL- 6 and iNOS through the inhibition of NFKB.

\section{Curcumin in diabetic peripheral vascular disease}

Up to $40 \%$ of cases relating to the development of foot ulcers has been reported to be due to PVD [25]. It mainly affects the peroneal and tibial arteries of the calf. The persistent hyperglycemic state leads to the endothelial cell dysfunction and smooth cell abnormalities develop in peripheral arteries [26]. It has been reported that the resulting decrease in endothelium-derived vasodilators causes vasoconstriction. The hyperglycemic state in diabetes results in an increase in thromboxane $\mathrm{A} 2$, a platelet aggregation agonist and a vasoconstrictor which in turn increases the risk of plasma hypercoagulability [27]. There is also the potential for alterations in the vascular extracellular matrix (ECM) which leads to stenosis of the arterial lumen. The other factors involved in the development of peripheral arterial disease in diabetic patients are hypertension, hyperlipidemia and smoking [28]. Cumulatively, this leads to occlusive arterial disease which results in an increased risk of ulceration and ischemia in the lower extremities of diabetic patients. The atherosclerotic plaques that occur in patients with diabetes are no different than those occurring in non-diabetics; in both, such plaques are composed of deposits of cholesterol. Curcumin has been reported to be active against diabetic PVD in many studies. Curcumin modulates the expression of protein kinase C (PKC)-, PKC-2, and mitogen-activated protein kinase (MAPK) in experimental diabetic cardiomyopathy [29]. It suppressed the accelerated accumulation of advanced glycation end-product (AGE) collagen and cross-linking of collagen in the tail tendons of diabetic rats by inhibiting vascular endothelial growth factor (VEGF), NF-B, and activator protein-1 (AP-1) [30]. Curcumin reduced both endothelial nitric oxide synthase (eNOS) and iNOS levels in high glucose stimulated microvascular endothelial cells of diabetic rat hearts [31,32]. It improved the endothelial cell dysfunction and PKC inhibition by its antioxidant activity in STZ-induced diabetic rats and mice [33,34]. It also improved the diabetes-induced vascular dysfunction by inhibiting COX-2, NF-B, and PKC activity in STZ rats [35]. Curcumin enhanced deregulated vascular contractility by reducing TNF- and aortic Reactive oxygen species (ROS) by inducing heme oxygenase (HO-1) in diabetic rats [36].

\section{Curcumin in diabetic foot infections (DFIs)}

Diabetic patients commonly suffer with foot infections which are associated with a high mortality rate, aside from a risk of lower extremity amputation. These infections are mostly caused by grampositive bacteria, such as $\beta$-hemolytic Streptococci and Staphylococcus aureus (S. aureus) while being divided into three categories i.e., mild, moderate, and severe. Diabetic patients are prone to infections of the foot which produce severe effects in them and cause deep infections of the bone. Aerobic gram-positive bacteria are the most common pathogens of acute foot infection in diabetic patients, particularly $\beta$ hemolytic streptococci (group A, B, and others) and $S$. aureus, whereas anaerobic bacteria are usually a part of mixed infections in patients with foot gangrene or ischemia [37]. Methicillin-resistant $S$. aureus (MRSA) is a more common pathogen in patients who have recently received antibiotic therapy or who have been previously informed in a hospital. Because of the increasing prevalence of MRSA in the community, the risk of contracting this infection is high [38]. The broad-spectrum antimicrobial activity of curcumin has been evidenced by several studies. In fact, there are no reported side effects at higher doses (12g/day), proven by clinical trials in humans [39]. Due to prolonged antimicrobial activity of curcumin, it has been used as a structural mannequin for the design of novel antimicrobial agents with modified and increased antimicrobial activities through the synthesis of various derivatives related to curcumin $[40,41]$. Even though specifically no in vitro or preclinical studies have been reported on the efficacy of curcumin in treating DFIs, it has proven to be effective in vitro against a wide range of bacteria which are most commonly found in DFIs. For instance, the antibacterial study on aqueous extract of Curcuma longa rhizome demonstrated the minimum inhibitory concentration (MIC) value of $4-16 \mathrm{~g} / \mathrm{ml}$ and $\mathrm{MBC}$ (minimum bactericidal concentration) value of $16-32 \mathrm{~g} / \mathrm{ml}$ against $\mathrm{S}$. epidermis (ATCC 12228), S. aureus (ATCC 25923), Klebsiella pneumoniae (ATCC 10031), and E. coli (ATCC 25922) respectively [42]. The methanol extract of turmeric has demonstrated MIC values of $16 \mathrm{~g} / \mathrm{ml}$ and $128 \mathrm{~g} / \mathrm{ml}$ against Bacillus subtilis and S. aureus [43]. Curcumin also exhibited inhibitory activity on MRSA with MIC value of 125-250 $\mathrm{g} / \mathrm{ml}[17]$.

\section{Curcumin as anti-inflammatory}

Unlike acute wounds, chronic wounds like DFUs remain static at the chronic inflammatory stage. Curcumin mediated inflection of inflammation occurs by disallowing the production of tumor necrosis factor. Two dominant cytokines liberated from macrophages and monocytes i.e., TNF- $\alpha$ and IL-1 play remarkable roles in the regulation of inflammatory response [6]. A transcription factor NFKB, that modulates many genes which are suspected in the commencement of inflammatory responses can be inhibited equally with the help of curcumin. This transcription factor is provoked by numerous kinases (Protein kinase B (PKB), phosphoinositide 3-kinase (PI3K), I kappa B kinase $(\mathrm{IKK})$ ) and curcumin disturbs a variety of the pathways occurred in this event [44]. The down regulation of the assertion of $\mathrm{P} 13 \mathrm{~K}$ and Protein kinase B (PKB/AKT kinases) are also shown which in turn leads to reduced activation of the NFkB gene and decreases inflammation. It was noticed that the prohibition of $\mathrm{NF \kappa B}$ pathway is due to the up regulation in IkB-a protein. Hence, Mohanty et al. [44] revealed that curcumin decreases inflammation at wound sites caused by the stimulation of the NFkB pathway. Conflicting to Mohanty's conclusion, an in vivo study of Kulac et al. reported an increase in inflammatory cell infiltration to burn wounds on rats in curcumintreated groups compared to untreated groups [45]. Curcumin, by decreasing the inflammation response of the wrecked skin, enters into the subsequent stage of healing and thereby promotes the wound healing process.

\section{Curcumin as an anti-oxidant}

Free radicals are contemplated to be the prime basis of inflammation in the wound healing process of DFUs [44]. ROS are the products of aerobic respiration which are important in biochemical and cellular processes, including cell progression, apoptosis, intracellular messaging, differentiation, and immunity [46]. ROS are also associated with wound healing, as they are required as an immune system defense against microorganisms. However, human cells get injured due to higher concentrations and prolonged presence of ROS as it develops oxidative stress, which result in inhibition of tissue remodeling $[47,48]$. In determining the amount of free radicals, the results obtained by ROS [hydrogen peroxide $(\mathrm{H} 2 \mathrm{O} 2)$ and superoxide 
Page 5 of 6

$(\mathrm{O} 2-)]$ are used as markers [46]. ROS as a free radical can result in oxidative damage, DNA breakage and enzyme inactivation, leading to lipid peroxidation, all of which inhibit optimum wound healing. ROS is the major cause of inflammation during wound healing activity [44]. Free radicals also mark and spoil proteins in tissues and for this reason they must be satisfactorily tramped. Antioxidant enzymes such as catalase, glutathione peroxidase and superoxide dismutase secure human cells against toxic ROS [49]. Topical application of antioxidants with free radical scavenging potential can appreciably help in wound healing [50]. Kant et al. [51] have studied the antioxidant and anti-inflammatory potential of curcumin and reported an accelerated cutaneous wound healing process in STZinduced diabetic rats. They found that curcumin application increased the wound contraction and decreased the expression of inflammatory cytokines (TNF- $\alpha$, IL-1 $\beta$ and matrix metalloproteinase-9). Curcumin also increased the levels of anti-inflammatory cytokine IL-10 and antioxidant enzymes, viz., superoxide dismutase (SOD), catalase and glutathione peroxidase.

\section{Curcumin as a proliferative agent}

The proliferative phase of wound healing involves granulation tissue formation, collagen deposition, fibroblast proliferation, epithelialization and apoptosis of unwanted cells. Granulation tissue formation, collagen production and deposition are based on the effective infiltration of fibroblasts into the wound bed [52]. Chronic wounds like DFUs fail to heal because of lack of fibroblast infiltration. Various studies have proven that curcumin can effectively infiltrate fibroblasts. Sidhu et al. [53] have detected myofibroblasts at wound sites of STZ induced diabetic mice treated with curcumin. Merrell et al. [54] have observed that curcumin loaded polymeric nanofibers exhibited a significant increase in the rate of wound closure $(80 \%)$ compared to those treated with control in STZ induced diabetic mice model. Kant et al. [53] have demonstrated that curcumin demonstrates acceleration in wound healing with marked collagen synthesis and fully regenerated epithelial layer in STZ induced diabetic rat model. In an another study, the same authors found improved neovasculogenesis in curcumin treated STZ induced diabetic rats by the increased expressions of VEGF, TGF- $\beta 1$, hypoxia-inducible factor (HIF)- $1 \alpha$, stromal cell-derived factor (SDF)-1 $\alpha$, and HO-1 [55].

\section{Conclusion}

On the whole, curcumin was found to exhibit various biological activities in treating DFUs via various mechanisms such as inhibition of activity of matrix metalloproteinases and proinflammatory cytokines (TNF- $\alpha$, IL-1 $\beta$; decreased inflammation and ECM degradation). It also inhibits mitogen activated protein kinases and suppression of lectin-like oxidized low density lipoprotein receptor-1 (LOX-1) up regulation (decreased nerve damage). Curcumin increases the levels of anti-oxidant enzymes (SOD, Glutathione peroxidase $(\mathrm{GPx})$ ) (decreased oxidative stress) and eNOS (decreased vascular occlusion). It also increases the levels of HO-1, VEGF, TGF- $\beta 1$ (promote angiogenesis) and SDF-1 $\alpha$, HIF-1a (vasculogenesis). However, despite these potential biological actions, clinical trials of curcumin are only available for treating diabetic retinopathy, nephropathy and microangiopathy until date. Hence, further studies are required in humans to prove the potential application of curcumin in DFU associated complications. In conclusion, the multiple biological activities of curcumin mentioned here clearly indicate its usefulness in treating various DFU-related complications.

\section{Conflict of Interest Statement}

The authors declare that there are no conflicts of interest involved in this study. The authors alone are responsible for the content and writing of the paper.

\section{Source of Funding}

This work was financially supported by the Department of Science and Technology (Government of India) under the scheme of INSPIRE Fellowship.

\section{Acknowledgments}

The author, Mr. V V S Narayana Reddy Karri wishes to express his gratitude to the Department of Science and Technology (DST), New Delhi, India for the award of INSPIRE Fellowship (IF130103, DST/ INSPIRE Fellowship/2013/70).

\section{References}

1. 10 Facts about Diabetes. Available at: http://www.who.int/features/ factfiles/diabetes/en/. [accessed on September 26, 2014].

2. Singh N, Armstrong DG, Lipsky BA (2005) Preventing foot ulcers in patients with diabetes. JAMA 293: 217-228.

3. Kruse I, Edelman S (2006) Evaluation and treatment of diabetic foot ulcers. Clin diabetes 24(2): 91-103.

4. Allen RJ Jr, Soares MA1, Haberman ID1, Szpalski C1, Schachar J1, et al. (2014) Combination therapy accelerates diabetic wound closure. PLoS One 9: e92667.

5. Apelqvist J, Ragnarson-Tennvall G, Larsson J, Persson U (1995) Longterm costs for foot ulcers in diabetic patients in a multidisciplinary setting. Foot Ankle Int 16: 388-394.

6. Akbik D, Ghadiri M, Chrzanowski W, Rohanizadeh R (2014) Curcumin as a wound healing agent. Life Sci 116: 1-7.

7. Radhakrishna K, VVS NRK, Baskaran M, Kuppusamy G (2014) Potential Use of Herbal Medicines in the Treatment of Diabetic Foot Ulcers. Med Sci 14(56): 34-42.

8. Brem H, Sheehan P, Boulton AJ (2004) Protocol for treatment of diabetic foot ulcers. Am J Surg 187: 1S-10S.

9. Falanga V (2005) Wound healing and its impairment in the diabetic foot. Lancet 366: 1736-1743.

10. Chand G, Mishra AK, Kumar S, Agarwal A (2012) Diabetic foot. Clinical Queries: Nephrology 1: 144-150.

11. Irving GR, Karmokar A, Berry DP, Brown K, Steward WP (2011) Curcumin: the potential for efficacy in gastrointestinal diseases. Best Pract Res Clin Gastroenterol 25: 519-534.

12. Balasubramanian $K$ (2006) Molecular orbital basis for yellow curry spice curcumin's prevention of Alzheimer's disease. J Agric Food Chem 54: 3512-3520.

13. Priyadarsini KI, Maity DK, Naik GH, Kumar MS, Unnikrishnan MK, et al. (2003) Role of phenolic O-H and methylene hydrogen on the free radical reactions and antioxidant activity of curcumin. Free Radic Biol Med 35: 475-484.

14. Ak T, Gülçin I (2008) Antioxidant and radical scavenging properties of curcumin. Chem Biol Interact 174: 27-37.

15. Meng B, Li J, Cao H (2013) Antioxidant and antiinflammatory activities of curcumin on diabetes mellitus and its complications. Curr Pharm Des 19: 2101-2113.

16. Liang G, Yang S, Zhou H, Shao L, Huang K, et al. (2009) Synthesis, crystal structure and anti-inflammatory properties of curcumin analogues. Eur J Med Chem 44: 915-919.

17. Mun SH, Joung DK, Kim YS, Kang OH, Kim SB, et al. (2013) Synergistic antibacterial effect of curcumin against methicillin-resistant Staphylococcus aureus. Phytomedicine 20: 714-718. 
18. Kulkarni SK, Dhir A (2010) An overview of curcumin in neurological disorders. Indian J Pharm Sci 72: 149-154.

19. Jeenger MK, Shrivastava S1, Yerra VG1, Naidu VG1, Ramakrishna S2, et al. (2015) Curcumin: A pleiotropic phytonutrient in diabetic complications. Nutrition 31: 276-282.

20. Osawa T, Kato Y (2005) Protective role of antioxidative food factors in oxidative stress caused by hyperglycemia. Ann N Y Acad Sci 1043: 440-451.

21. Sharma S, Chopra K, Kulkarni SK (2007) Effect of insulin and its combination with resveratrol or curcumin in attenuation of diabetic neuropathic pain: participation of nitric oxide and TNF-alpha. Phytother Res 21: 278-283.

22. Attia HN, Al-Rasheed NM, Al-Rasheed NM, Maklad YA, Ahmed AAE (2012) Protective effects of combined therapy of gliclazide with curcumin in experimental diabetic neuropathy in rats. Behav Pharmacol 23: 153161.

23. Zhao WC, Zhang B, Liao MJ, Zhang WX, He WY, et al. (2014) Curcumin ameliorated diabetic neuropathy partially by inhibition of NADPH oxidase mediating oxidative stress in the spinal cord. Neurosci Lett 560: 81-85.

24. Joshi RP, Negi G, Kumar A, Pawar YB, Munjal B, et al. (2013) SNEDDS curcumin formulation leads to enhanced protection from pain and functional deficits associated with diabetic neuropathy: an insight into its mechanism for neuroprotection. Nanomedicine 9: 776-785.

25. Huijberts MS, Schaper NC, Schalkwijk CG (2008) Advanced glycation end products and diabetic foot disease. Diabetes Metab Res Rev 24 Suppl 1: S19-24.

26. Zochodne DW (2008) Diabetic polyneuropathy: an update. Curr Opin Neurol 21: 527-533.

27. Paraskevas KI, Baker DM, Pompella A, Mikhailidis DP (2008) Does diabetes mellitus play a role in restenosis and patency rates following lower extremity peripheral arterial revascularization? A critical overview. Ann Vasc Surg 22: 481-491.

28. Armstrong DG, Lavery LA (1998) Diabetic foot ulcers: prevention diagnosis and classification. Am Fam Physician 57: 1325-1332, 1337-8.

29. Soetikno V, Sari FR, Sukumaran V, Lakshmanan AP, Mito S, et al. (2012) Curcumin prevents diabetic cardiomyopathy in streptozotocin-induced diabetic rats: possible involvement of PKC-MAPK signaling pathway. Eur J Pharm Sci 47: 604-614.

30. Sajithlal GB, Chithra P, Chandrakasan G (1998) Effect of curcumin on the advanced glycation and cross-linking of collagen in diabetic rats. Biochem Pharmacol 56: 1607-1614.

31. Farhangkhoee H, Khan ZA, Chen S, Chakrabarti S (2006) Differential effects of curcumin on vasoactive factors in the diabetic rat heart. Nutr Metab (Lond) 3: 27.

32. Srivastava G, Mehta JL (2009) Currying the heart: curcumin and cardioprotection. J Cardiovasc Pharmacol Ther 14: 22-27.

33. Patumraj S, Wongeakin N, Sridulyakul P, Jariyapongskul A, Futrakul N, et al. (2006) Combined effects of curcumin and vitamin C to protect endothelial dysfunction in the iris tissue of STZ-induced diabetic rats. Clin Hemorheol Microcirc 35: 481-489.

34. Rungseesantivanon S, Thenchaisri N, Ruangvejvorachai P, Patumraj S (2010) Curcumin supplementation could improve diabetes-induced endothelial dysfunction associated with decreased vascular superoxide production and PKC inhibition. BMC Complement Altern Med 10(1): 57.

35. Rungseesantivanon $S$, Thengchaisri N, Ruangvejvorachai P, Patumraj $\mathrm{S}$ (2010) Curcumin improves prostanoid ratio in diabetic mesenteric arteries associated with cyclooxygenase- 2 and NF-1 ${ }^{\circ} \mathrm{B}$ suppression. Diabetes Metab Syndr Obes 3: 421-429.

36. Hassan N, El-Bassossy HM, Zakaria MNM (2013) Heme oxygenase-1 induction protects against hypertension associated with diabetes: effect on exaggerated vascular contractility. Naunyn Schmiedebergs Arch Pharmacol 386(3): 217-226.
37. Bader MS (2008) Diabetic foot infection. Am Fam Physician 78: 71-79.

38. Tentolouris N, Petrikkos G, Vallianou N, Zachos C, Daikos GL, et al. (2006) Prevalence of methicillin-resistant Staphylococcus aureus in infected and uninfected diabetic foot ulcers. Clin Microbiol Infect 12: 186-189.

39. Moghadamtousi SZ, Kadir HA, Hassandarvish P, Tajik H, Abubakar S, et al. (2014) A review on antibacterial, antiviral, and antifungal activity of curcumin. Biomed Res Int 2014: 186864.

40. La Colla P, Tramontano E, Musiu C, Marongiu M, Novellino E, et al. (1998) Curcumin-like derivatives with potent activity against HIV-1 integrase: synthesis, biological evaluation and molecular modeling. Antiviral Res 37(3): A 57.

41. Anand P, Kunnumakkara AB, Newman RA, Aggarwal BB (2007) Bioavailability of curcumin: problems and promises. Mol Pharm 4: 807-818.

42. Niamsa N, Sittiwet C, (2009) Antimicrobial activity of Curcuma longa aqueous extract. J Pharmacol Toxicol 4(4): 173-177.

43. Ungphaiboon S, Supavita T, Singchangchai P, Sungkarak S, Rattanasuwan P, et al. (2005) Study on antioxidant and antimicrobial activities of turmeric clear liquid soap for wound treatment of HIV patients. Songklanakarin J Sci Technol 27(2): 269-578.

44. Mohanty C, Das M, Sahoo SK (2012) Sustained wound healing activity of curcumin loaded oleic acid based polymeric bandage in a rat model. Mol Pharm 9: 2801-2811.

45. Kulac M, Aktas C, Tulubas F, Uygur R, Kanter M, et al. (2013) The effects of topical treatment with curcumin on burn wound healing in rats. J Mol Histol 44: 83-90.

46. Imlay JA (2003) Pathways of oxidative damage. Annu Rev Microbiol 57: 395-418.

47. Panchatcharam M, Miriyala S, Gayathri VS, Suguna L (2006) Curcumin improves wound healing by modulating collagen and decreasing reactive oxygen species. Mol Cell Biochem 290: 87-96.

48. Thangapazham RL, Sharad S, Maheshwari RK (2013) Skin regenerative potentials of curcumin. Biofactors 39: 141-149.

49. Kapoor S, Priyadarsini KI (2001) Protection of radiation-induced protein damage by curcumin. Biophys Chem 92: 119-126.

50. Martin A (1996) The use of antioxidants in healing. Dermatol Surg 22: 156-160.

51. Kant V, Gopal A, Pathak NN, Kumar P, Tandan SK, et al. (2014) Antioxidant and anti-inflammatory potential of curcumin accelerated the cutaneous wound healing in streptozotocin-induced diabetic rats. Int Immunopharmacol 20: 322-330.

52. Singer AJ, Clark RA (1999) Cutaneous wound healing. N Engl J Med 341: 738-746.

53. Sidhu GS, Mani H, Gaddipati JP, Singh AK, Seth P, et al. (1999) Curcumin enhances wound healing in streptozotocin induced diabetic rats and genetically diabetic mice. Wound Repair Regen 7: 362-374.

54. Merrell JG, McLaughlin SW, Tie L, Laurencin CT, Chen AF, et al. (2009) Curcumin-loaded poly(epsilon-caprolactone) nanofibres: diabetic wound dressing with anti-oxidant and anti-inflammatory properties. Clin Exp Pharmacol Physiol 36: 1149-1156.

55. Kant V, Gopal A, Kumar D, Pathak NN, Ram M, et al. (2015) Curcumininduced angiogenesis hastens wound healing in diabetic rats. J Surg Res 193: 978-988.

56. Sajithlal GB, Chithra P, Chandrakasan G (1998) Effect of curcumin on the advanced glycation and cross-linking of collagen in diabetic rats. Biochem Pharmacol 56: 1607-1614.

57. Jeon Y, Kim CE, Jung D, Kwak K, Park S, et al. (2013) Curcumin could prevent the development of chronic neuropathic pain in rats with peripheral nerve injury. Curr Ther Res Clin Exp 74: 1-4.

58. Banafshe HR, Hamidi GA, Noureddini M, Mirhashemi SM, Mokhtari R, et al. (2014) Effect of curcumin on diabetic peripheral neuropathic pain: possible involvement of opioid system. Eur J Pharmacol 723: 202-206. 